Eiyad S. Al-Kutubi. Mulla Șadrā and Eschatology: Evolution of Being. London \& New York: Routledge, 2015. vii+ 151 pages. ISBN: 9781138794160.

\title{
Sümeyye Parıldar*
}

In customary fashion, al-Kutubi opens his book with a general summary of his intention and central argument. He presents the central issue, Sadrian eschatology by placing Mulla Șadrā's (d. 1050/1641) Zād al-Musāfir in the center in order to deepen the ensuing discussion without being distracted by related concepts and discussions. In this way, al-Kutubi enlarges the discussion, when required, by delving into Șadrā's other books (e.g., Al-Asfar al-Arba'a, Al-Mabda' wa al-Ma'ād, Shawāhid al-Rubūbìya, Al-Hikma al-'Arshìya, and Tafsìr al-Qur'ān), or evaluating the concepts discussed in Zād al-Musāfir and going into the theoretical details of related concepts while staying focused on eschatology.

Mulla Șadrā is famous for his attempt to provide philosophical arguments for theological matters that are basically built on scriptural evidence. Thus, al-Kutubi establishes his account of Sadrian eschatology on the original conceptual and theoretical framework put forward by Mulla Șadrā himself. This loyalty does have a certain advantage, but it also makes the reader wonder if the author will offer anything beyond what is already in Șadrā's book. The book is a detailed analysis of the basic axioms stated by Mulla Șadrā in Zād al-Musāfir and how they relate to eschatology. Accordingly, the chapters are entitled "Primacy of Existence," "Individuation," "Substantial Motion," "The Nature of Human Being," "Imagination and the Problem of Bodily Return," and Șadrā’s theories of Imagination and Bodily Return."

Zād al-Musāfir presents various principles that summarize Șadrā's theory and relates the basic principles upon which he based his theory of eschatology: i) existence supervenes quiddity (așālat al-wujūd); ii) individuation and existence are identical in reality but different in name and consideration; iii) existence manifests itself in differing degrees and intensities, weakness and strengths; iv) the form is identical

\section{Dr., İstanbul University, Faculty of Theology.}


to the reality that makes the thing itself; v) the body is secondary to and defined by the soul; vi) the imaginative faculty is a substance that is located between the body and soul (i.e., it is independent of the body) and therefore its locus is not the material realm; vii) the soul is not the container of the imaginative form because the latter does not inhere in the former; rather this form is maintained by the soul; viii) vision occurs when the form that is identical to the form in the extramental world is created; ix) despite multiplicity, existence is one; $\mathrm{x}$ ) human beings can manifest many instantiations of being successively; xi) death is a result of the soul's perfection; xii) God created the soul in such a way that it can create forms that are not similar to the ones in material senses; xiii) human states can lead to external effects; and xiv) the individual unity of each thing also includes a gradual process of evolving (4-5).

It is no accident that Mulla Șadrā eschatology is built upon a list of principles that cover almost all important theoretical issues, for how else could he formulate a holist and systematic system? Unsurprisingly, the list in Zād al-Musāfir mirrors another group of principles in Asfär. Another reason for such a comprehensive list is the peculiarity of eschatology in his philosophy, which, when inserted into the larger context of the history of ideas, might be interpreted as Mulla Șadrā's response to al-Ghazālī's (d. 505/1111) attack on philosophers. However, the author neither dwells on issues of this nature nor tries to contextualize Sadrian eschatology in the history of philosophy - other than the places where Sadrā himself deals with the concept's history (90-93).

Mulla Șadrâ's treatment of theoretical issues is historical or contextual, in the loose sense of those terms, for he starts by relating previous discussions on each topic and the different clusters of disagreements. His composition of the text is almost always carried on by his statement that he disagrees with all previous claims. Thus it is no surprise that here, he similarly gives the scriptural sources on eschatology used by the theologians to devise their own readings of it and later describes the theories of the Peripatetics, al-Suhrawardì (d. 587/1191), and Ibn al-Arabì (d. $638 / 1240$ ) on resurrection. Although his theory depends heavily on Ibn al-AArabī's notion of imagination, he does not commit to any of these groups' claims. Al-Kutubi traces the concept's history and attempts to understand the scriptural evidence on bodily resurrection in relation to such concepts as the soul and original particles (al-ajza' al-juz'ìya) (11). Theologians began to raise theories on related topics from the eleventh century onward. Avicenna's (d. 428/1037) approach consisted of maintaining symbolic language as a characteristic of religious discourse (12). Mulla Șadrā found flaws in the theologians' solution, as it was based on premises that 
contradicted the laws of nature and reason, whereas the philosophers' insistence on symbolic usage of the Scripture, which presents resurrection as figurative, is simply wrong. At this point, al-Kutubi separates Șadrā from Avicenna, al-Fārābī (d. 339/950), and even al-Suhrawardi on the ground that the others lack the essential expertise for undertaking Qur'anic exegesis (4).

After dealing Mulla Șadrā's listing of his system's essential principles at the beginning of Zād al-Musāfir, al-Kutubi explains this philosopher's theories of existence, individuation, substantial motion, and the nature of the human being. The problem of bodily resurrection is translated into an issue of bodily resurrection, wherein individuation is preserved. The process for this account are provided through substantial motion, and its central concept is imagination. A theory of bodily resurrection should explain both how the body is restored after it has been destroyed and should avoid any implication of transmigration (tanāsukh) (119). At this point, the principle that assures continuity and individuality is explained through the faculty of imagination.

Mulla Sadrā establishes existence as the sole source of all reality. Defined as the principle of both oneness and multiplicity, it separates individual things from each other and thus it is also the principle of individuation. Each existent, including human beings, changes in its essence as soon as it comes into existence. Thus the Sadrian system avoids the body-soul duality through essential movement (al-haraka al-jawharì). Human beings are material at the beginning of their existence, but become immaterial during the process by which essential movement deprives them of their former connection to materiality (123-24). The human being's developmental stages are regarded as stages of existence and stages of reality, and each person becomes an imaginative being at the second stage (110 ff).

For Mulla Șadrā, "imagination" refers to something beyond a faculty of the soul or a connection provider between the material and immaterial realms, for it enables human beings to change from one species of being into another (124). Al-Kutubi's presentation of the imaginative power in a way designed to comprehend the external senses exemplifies his careful reading of Șadrā's texts. In recognition of the importance of this expanded reading, he entitles it a "creative perception," which reminds us of Corbin's "creative imagination"1 (105-12).

1 As much as Henry Corbin is the name to remember when referring to the creative imagination, I should add that William Chittick's enormous body of work on Ibn al-'Arabī is also built on the creative nature of imagination. William Chittick, The Sufi Path of Knowledge: Ibn al-Arabi's Metaphysics of Imagination (Albany: SUNY Press, 1989); Henry Corbin, Alone with the Alone: Creative Imagination in the Süfism of Ibn 'Arabi (Princeton, NJ: Princeton University Press, 1998). 
According to al-Kutubi, Șadrā's identification of the second stage of existence with the imaginative faculty makes his overall theory authentic. Although the material body undergoes change and disappears in time, it is still included in being by the higher stage, namely, the imaginative body. At this point, resurrection is not only a matter of religious belief, but becomes a "natural stage" in the due course of human evolution (124).

Al-Kutubi portrays Șadrā's theory, which is mainly built upon the Holy Script, as a proof for the hermeneutical importance of the Sadrian transcendental wisdom project (al-ḥikma al-muta'ālìya) (124-25). He opens a window for more detailed future studies on a Sadrian interpretation of the Qur'an and the hermeneutic method by drawing our attention to the authenticity of Șadrā's reading and how the Qur'an played a central role in this theoratization.

This research, being an important source with clear-yet-intensive analyses on Mulla Șadrā, represents a contribution to Mulla Șadrā studies that will not only benefit the experts, but also those who are unfamiliar with his theoretical framework. In addition, al-Kutubi contextualizes this philosopher in the scholarly background of discussions on resurrection, at which point Șadrā's own presentation should have been influential. Additionally, he reconstructs and expands Sadrā's discussion in Zād al-Musāfir with the aid of other Sadrian texts. Having said this, and despite his detailed analysis, al-Kutubi nevertheless fails to bring out the exact contribution of this particular theory of eschatology by recontextualizing its importance in Islamic thought. One of the reasons for this might be that the author does not explain how his own book contributes to the literature. Moreover, despite all of the references and usage of the secondary literature on Sadrā, the author seems not to have been attracted to some research on Sadrian eschatology, such as the short evaluation of Latimah-Parvin Peerwani ${ }^{2}$ and Christian Jambet's book. ${ }^{3}$ However, the academic audience should be grateful for al-Kurtubi's careful and detailed reading, which presents a clear explanation of Sadrian theories, and the contribution of such an intense text to the literature. This book will require the same amount of attention and eye for detail from its readers.

2 Latimah-Parvin Peerwani, "Mullâ Sadrâ: Provision for a Traveler on the Spiritual Path to Being (Zâd al-Musâfir)," Ishraq: Islamic Philosophy Yearbook, no. 6 (2015): 71-86.

3 Christian Jambet, L’Acte d'Être: la Philosophie de la Révélation chez Mollâ Sadrâ (Paris: Fayard, 2002); The Act of Being: The Philosophy of Revelation in Mullā Sadrā, trans. Jeff Fort (New York: Zone Books, 2006). 